\title{
FORMATION OF SPIRITUALITY OF CADETS \\ IN FRAMEWORKS OF HIGHER EDUCATION INSTITUTION
}

\section{ФОРМУВАННЯ ДУХОВНОСТІ КУРСАНТІВ \\ В УМОВАХ ЗАКЛАДУ ВИЩОЇ ОСВІТИ}

\section{Koba Oleksandr ${ }^{1}$ \\ Koba Maria ${ }^{2}$}

DOI: https://doi.org/10.30525/978-9934-571-78-7_19

\begin{abstract}
The article deals with theoretical generalization and scientific solution of the problem of forming the spirituality of cadets in the conditions of the institution of higher education. On the basis of the analysis of scientific sources on psychology, pedagogy, the subject of the research is grounded-theoretical and methodological principles of the formation of the spiritual values of the individual. The purpose of the research: to carry out a comprehensive substantiation of the problem of forming the spirituality of cadets in the educational process of higher education institution. Today, as a result of the lack of elaboration of the aspects of content and value domains of higher professional education, institutions of higher education, in most cases, act as a conservative «distributor» of professional knowledge, which looses the spiritual component of the personality of a future officer. The study clarifies the essence of the concept of «upbringing», «youth», «spiritual life of society», «spiritual world of personality». The potential of social and humanitarian disciplines and non-auditing activities of the institution of higher education regarding the formation of cadets' spiritual values on the basis of a set of principles is revealed: axiological (understanding of man as the highest value, orientation on spirituality as one of the defining characteristics of the value of higher education); personally oriented (taking into account the regularities of the natural and socio-cultural development of the individual, organizing the educational process in the context of the culture of civilization
\end{abstract}

\footnotetext{
${ }^{1}$ Candidate of Pedagogical Sciences, Deputy Head of the Department of Military-Combat Application of Units, National Guard of Ukraine of the Kiev Faculty of the National Academy of National Guard of Ukraine, Ukraine

${ }^{2}$ Senior Lecturer of the Department of Legal Assistance to the Military Activities, Kyiv Faculty of the National Academy of National Guard of Ukraine, Ukraine

(C) Koba Oleksandr, Koba Maria
} 


\section{Koba Oleksandr, Koba Maria}

and a certain people); activity (satisfaction of interests and needs of the cadet in various types of spiritual and practical activities, stimulation of a young person to independent spiritual search). The observance of the above principles does not lose its relevance at each of the stages of the formation of the spirituality of the chimes, namely: cognitive-reflexive (expansion of knowledge about the spiritual foundation of a certain professional discipline), value-semantic (understanding the peculiarities of the development of their own spiritual self in the process of internalization of the spiritual spiritualist acquired from the teacher knowledge); activity-translational (formation of an appraisal relation to the phenomena of the surrounding reality, the realization of the aspiration of independent spiritual and practical activity, exteriorization of the acquired experience of spiritual knowledge). The system of spiritual education of cadets should be open to nature. It is closely connected not only with the activity of the internal structural subdivisions of the ZVO and the directions of the educational process, but also constantly interacts with the external environment, which, in turn, has a significant impact on the formation and strengthening of the existing system of educational work. Conclusions. Higher school is able to solve an extremely complex social task with regard to the formation of not only a true professional, but also a highly spiritual personality. Proper attention to artistic education, the creation of an appropriate cultural environment within the institution of higher education capable of providing predictable educational impacts. Actualization of the value dominant of higher professional education, overcoming the artificial knowledge limitations of professional training, the disclosure of the axiological potential of each of the disciplines and the full use of educational opportunities of the subjects of the culturological cycle. The integration of internal and external conditions for the development of the spirituality of cadets and the concentration of educational efforts of the whole teaching staff is quite capable of significantly improving the efficiency of the formation of this integrative professional qualitative quality of the future officer, encouraging him to consciously and consistently focusing on spiritual values in personal self-improvement and interpersonal interaction.

\section{1. Ветуп}

Соціально-економічні перетворення в Україні, глобалізаційні виклики, орієнтація на створення спільного Європейського простору вимагають суттєвих змін у системі вищої освіти, зокрема створення 


\section{Chapter «Pedagogical sciences»}

такого освітнього середовища, що забезпечить виховання особистості, якій властиві духовні цінності та високий рівень культури.

Упродовж останніх десятиліть в Україні змінилася соціокультурна ситуація, яка позначається багатьма негативними тенденціями: зростання нетерпимості й агресії у взаєминах між людьми, втрата життєвих орієнтирів у певної частини молоді тощо. 3 огляду на це заклади вищої освіти покликані стати соціальним інститутом, що виконує випереджальну роль у становленні особистості молодої людини, формуванні ії світогляду та здатності до самореалізації в суспільстві на основі духовних цінностей.

У стратегічних документах освітньої галузі України, зокрема в Законі України «Про вищу освіту», Концепції виховання дітей та молоді в національній системі освіти, Концепції національно-патріотичного виховання дітей та молоді, Стратегії національно-патріотичного виховання дітей та молоді на 2016-2020 роки, акцентується потреба утвердження в освіті особистісно зорієнтованого підходу, який передбачає не лише засвоєння людиною певного обсягу професійних знань, умінь, навичок, а й забезпечення гармонійного співвідношення ії творчих і професійних якостей, розвиток неповторної індивідуальності.

За сучасних умов студентська молодь є головним суб'єктом реформування та інноваційного розвитку вищої освіти і суспільства загалом, тому проблема формування духовності курсантів в умовах закладу вищої освіти набуває високої актуальності.

Філософське обгрунтування феномену цінностей здійснено у працях Аристотеля, Ф. Бекона, В. Віндельбанда, М. Гартмана, Г. Гегеля, T. Гоббса, Е. Гуссерля, Р. Декарта, І. Канта, Г. Лейбніца, Р. Лотце, Ф. Ніцше, Т. Парсонса, Платона, Г. Ріккерта, Б. Спінози, М. Шеллера. Чільне місце означене питання посідає у дослідженнях сучасних філософів Г. Вижлецова, О. Золотухіної-Аболіної, О. Дробницького, М. Кагана, К. Клакхона, О. Корнієнка, В. Ольшанського, Р. Перрі, Д. Рісменома, М. Сміта, М. Тофтула та інших, котрі визначають їх як суспільно значущі орієнтири діяльності особистості.

Осмисленню духовності присвячено праці українських і зарубіжних психологів: С. Белорусова, М. Боришевського, О. Климишина, М. Ломова, А. Маслоу, В. Москальця, Е. Помиткіна, С. Пролеєва, М. Савчина та інших. Значний науковий доробок щодо формування духовності особистості представлений у вітчизняній педагогічній 
думці, зокрема у працях М. Демкова, О. Духновича, М. Корфа, І. Огі-

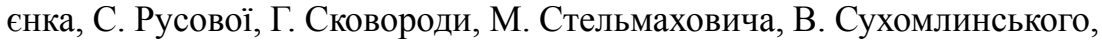
К. Ушинського, Я. Чепіги.

Методологічне підгрунтя духовного становлення і розвитку особистості в умовах реформування освіти визначено у дослідженнях I. Беха, О. Вишневського, В. Жуковського, І. Зязюна, В. Кременя, Л. Москальової, А. Осіпцова, Т. Потапчук, О. Сухомлинської, В. Тернопільської, Г. Шевченко.

Проте питання формування духовності курсантів в умовах закладу вищої освіти не знайшло на даний час достатнього розкриття в контексті педагогіки, що зумовлює доцільність обгрунтування проблеми.

На сьогодні внаслідок недостатньої розробленості аспектів змісту та ціннісних домінант вищої професійної освіти ЗВО (закладів вищої освіти) здебільшого діє як консервативний «розподільник» фахових знань, за якими губиться духовна складова особистості майбутнього офіцера. Така ситуація дає змогу окреслити такі суперечності:

- між об'єктивною потребою суспільства в активних творчих особистостях із розвиненою системою духовних орієнтирів, здатних до духовно-практичної діяльності та трансляції духовних цінностей та ідеалів, і нерозробленістю конкретних шляхів формування духовності майбутнього офіцера в період загальнопрофесійної підготовки;

- між більш чи менш виразним аксіологічним потенціалом кожної 3 фахових дисциплін у формуванні духовності курсантів і надмірною «вагою» в освітньому процесі знаннєвого компонента змісту вищої освіти;

- між загостренням потреби освітньої практики в науково-методичному забезпеченні формування духовної культури курсанта та відсутністю грунтовних розробок із цієї проблематики.

Актуальність проблеми в сучасних умовах розвитку країни, потреба iii теоретичного та практичного розроблення й систематизації, а також визначені суперечності зумовили вибір теми дослідження: «Формування духовності курсантів в умовах закладу вищої освіти».

\section{2. Теоретико-методологічні засади}

\section{проблеми формування духовності курсантів}

Здійснено аналіз наукових джерел з психології, педагогіки, обгрунтовано теоретико-методологічні засади формування духовних цінностей особистості; досліджено проблему формування духовних 


\section{Chapter «Pedagogical sciences»}

цінностей в історико-педагогічній ретроспективі; на основі актуалізованих підходів до визначення сутності базових понять («виховання», «молодь», «духовне життя суспільства»), уточнено сутність поняття ««духовний світ особистості».

Виховання виявилося б зайвим життєвим етапом, якби людина народжувалася самостійною і завершеною істотою, приходила у світ тілесно, духовно та соціально зрілим індивідом. Але річ у тім, що дитина протягом тривалого часу залишається приреченою на опіку i допомогу з боку батьків, оточення і суспільства в цілому. Виховання покликане сприяти виживанню людства. Воно є одним 3 вагомих чинників антропосоціогенези, забезпечуючи дію механізмів соціальної спадкоємності.

Виховання грунтується на екзистенційно важливих процесах та етапах людського життя - таких, як народження і смерть, зміна генерацій тощо. Саме тому в усіх без винятку суспільствах виховання не лише існує, а й послідовно нарощує свій функціональний потенціал. Воно є не лише можливістю, а й необхідністю індивідуально-особистісного та суспільного життя. Виховання завжди спрямовано у майбутнє, $є$ тим специфічним культурним інструментом, за допомогою якого людина створює та ієрархізує майбутнє. Воно здійснюється в межах конкретних соціальних і культурних умов та обставин. Конкретно-історичний формат виховання залежить від родини, культури та суспільних відносин, в межах яких здійснюється соціалізація індивіда. Слід розмежовувати виховання та соціалізацію. Соціалізація - дещо ширше поняття: воно описує процес суб'єктивного засвоєння суспільних структур, типових соціальних ролей, домінуючих норм та цінностей, необхідних для входження людини до системи суспільних відносин. На відміну від соціалізації, яка може бути спонтанною і неусвідомленою, виховання $є$ цілком свідомим, цілеспрямованим впливом на особистість; це частина широкого процесу соціалізації, що відбувається переважно в дитинстві та юності.

Виховання є як повсякденним, так і універсальним феноменом. Повсякденний досвід виховання не потребує філософської рефлексії. Часто він $є$ фрагментарним, непослідовним, несистематичним. Виховання, якщо воно спирається тільки на повсякденний досвід, здебільшого виявляється однобічним і неефективним. 


\section{Koba Oleksandr, Koba Maria}

Духовне життя суспільства - надзвичайно важливий елемент як окремого індивіда, так і соціума загалом. Від оптимальності цього процесу залежать перспективи еволюціонування суспільства в цілому. В основі розвитку духовного життя суспільства та виховання як однієї 3 його невід'ємних складових лежить духовне виробництво, яке здійснюється в нерозривному взаємозв'язку з іншими видами суспільного виробництва. Духовне виробництво $є$ насамперед формуванням духовних потреб людей, виробництвом суспільної свідомості.

Молодь - надзвичайно важлива складова суспільства. ії політична культура перебуває в стадії формування. Соціалізація молодого покоління залежить від динаміки засвоєння норм, цінностей, досвіду та традицій політичного буття. Невід'ємним атрибутом сучасної молоді $\epsilon$ розмитість буттєвих орієнтирів, відчуження від соціальних інститутів і зневіра в можливості реалізації на практиці демократичних принципів. Серед молоді простежується споживацький підхід до життя, поширення цинізму та соціальної апатії. Це стосується і відношення до суб'єктів політичного життя країни, що має і матиме в подальшому негативні наслідки для перспектив сприйняття демократичних моделей розвитку суспільства.

Одним з основних чинників у процесі формування молодого покоління є модель соціально-економічного розвитку держави, ставлення суб'єктів до власності, до своїх прав та обов'язків. У виховному процесі необхідно враховувати, що решта чинників виявляються істотно залежними від зазначеного.

Водночас варто зауважити, що твердження, згідно з яким сучасне молоде покоління має вкрай низький рівень політичної культури, не зовсім, не завжди і не в повній мірі відповідає дійсності. Коректніше вести мову про неостаточну сформованість і невиразність вияву різних елементів політичної культури. Молодь здатна бути не лише носієм політичної культури, а й творити іï, генерувати політичні ідеї та діï, надихати «прогресивні суспільні перетворення. Вона є тією соціальною групою, котра здатна модернізувати суспільство, звільнити його від старих стереотипів мислення. Для цього потрібна всебічна підготовка до життя в суспільстві, необхідне істотне підвищення рівня політичної культури. Розв'язання цієї проблеми має здійснюватися на різних рівнях: загальному (соціально-політичному), особливому (науковому) та одиничному (педагогічному). Викладачі закладів вищої 


\section{Chapter «Pedagogical sciences»}

овіти повинні враховувати, що молодь очікує від них підтримки та допомоги у зрозумінні складних процесів, котрі відбуваються в державі, та суспільстві.

Існує широка палітра різноманітних підходів, окремих концепцій, методів дослідження духовного розвитку особистості: моральні та етичні сторони духовності (І. Зязюн та С. Гончаренко); формування духовної культури учнівської молоді засобами мистецтва (Г. Шевченко); роль духовних цінностей як смислоутворювального ядра духовності (О. Сухомлинська); педагогіка духовного потенціалу особистості в контексті музичного мистецтва (О. Олексюк, М. Ткач); розвиток духовного потенціалу особистості (М. Савчин); питання духовної самореалізації особистості (Г. Балл); формування духовної особистості з християнсько-філософської позиції на принципах християнської моралі (Г. Васянович, В. Жуковський, В. Крижанська, С. Новоселецька, В. Рачковська та інші).

Поняття «духовний світ особистості» детермінується сутністю таких понять як духовність та внутрішній світ особистості. Перше i $\epsilon$ відображенням другого, а саме, духовність - це те чим наповнена свідомість, емоційно-чуттєва сфера, мислення та засвоєна інформація, яка відображує змістовне багатство особистості у відношенні як до самої себе, так і до навколишнього світу.

Великий український педагог В. Сухомлинський убачав формування духовного світу особистості в єдності трьох напрямів виховного впливу на їі розумовий, моральний та естетичний розвиток, підкреслюючи, що сфера духовного життя людини - це розвиток, формування й задоволення його моральності, інтелектуальних і естетичних запитів й інтересів у процесі активної діяльності. Джерелом духовного світу людини є матеріальний світ, об'єктивна дійсність й особливо такі важливі їі сфери, як громадське життя людини, іiі соціальний і моральний досвід.

На підставі здійсненого теоретичного аналізу уточнено зміст поняття «виховання», «молодь», «духовне життя суспільства», «духовний світ особистості», як інтегральне особистісне утворення, спрямоване на інших людей (відповідальність, толерантність, милосердя) та на себе (гідність, самодостатність), що робить поведінку конструктивною та забезпечує можливість здійснення суб'єкт-суб'єктної взаємодії, адаптацію та самореалізацію особистості в суспільстві. 


\section{Koba Oleksandr, Koba Maria}

\section{3. Методичні засади формування духовності курсантів у навчально-виховному процесі 3ВО}

Представлено змістово-методичне забезпечення формування духовності курсантів під час навчання та в позааудиторній діяльності відповідно до визначених педагогічних умов.

Сучасний соціально-економічний, науково-технічний і культурний розвиток суспільства поставив перед вищою школою завдання сформувати не лише справжнього професіонала, котрий володіє грунтовними фаховими знаннями, а й високодуховну особистість. Разом з тим слід зазначити, що притаманна вищій освіті побудова навчального процессу не сприяє динамічному розмаїттю спрямованих на досягнення названої мети впливів.

У такій ситуації вкрай гострою стає не лише необхідність переакцентування завдань професійної освіти на належну увагу до формування духовності курсантів та на реальне повернення категорії «духовність» у педагогічну науку, а й зосередження дослідників-практиків на осмисленні змісту та пошуках найефективніших шляхів духовного розвитку сьогоднішнього студентства в сучасних соціокультурних умовах. Зі свого боку, розуміючи духовність майбутнього офіцера як інтегративну професійно значущу якість особистості, що характеризується орієнтацією на духовні цінності культури в особистісному саморозвитку та міжособистісній взаємодії, до основних критеріїв iii сформованості вважаємо за доцільне зарахувати: культурну компетентність, представленість духовно-культурних цінностей в аксіологічному потенціалі особистості, емпатійність, цілепокладання у сфері духовного життя і включеність курсанта у духовно-практичну діяльність. 3 огляду на це, формування духовності курсантів повинно передбачати: інтеграцію знань про цінності духовної культури, розвиток духовного світу молодої людини, збагачення духовних потреб, розширення досвіду духовного пізнання на основі активізації духовно-практичної діяльності та прагнення до духовного самовдосконалення. Сам процесс формування духовності у закладі вищої освіти, на нашу думку, охоплює: конструювання педагогом ситуацій проживання нового досвіду; штучне створення в стінах ЗВО середовища, здатного здійснити певний передбачуваний виховний вплив, інтеграцію внутрішніх та зовнішніх умов розвитку, цілеспрямоване стимулювання дії факторів розвитку особистості. 


\section{Chapter «Pedagogical sciences»}

Оскільки головною сферою соціальної активності курантів $\epsilon$ навчання, тож саме у ставленні до нього, в оцінці значення набутих знань, культурі читання спеціальної літератури, прагненні до успіхів у професійному зростанні найбільш виразно виявляється рівень розвитку духовності, якого досягнув конкретний курсант. Допомогти йому 3 максимальною ефективністю використати роки навчання у ЗВО для «сходження» до вершин духовності педагог зможе, поклавши в основу викладання свого предмета сукупність принципів: аксіологічного (розуміння людини як найвищої цінності, орієнтація на духовність як одну з визначальних характеристик цінності вищої освіти); особистісно орієнтованого (урахування закономірностей природного та соціокультурного розвитку особистості, організація навчального процесу в контексті культури цивілізації та певного народу); діяльнісного (задоволення інтересів та потреб курсанта у різних видах духовно-практичної діяльності, стимулювання молодої людини до самостійного духовного пошуку).

Зауважимо, що дотримання вказаних принципів не втрачає актуальності на кожному з етапів формування духовності курантів, а саме: когнітивно-рефлексивному (розширення знань про духовне підгрунтя певної фахової дисципліни), изінісно-смисловому (осмислення особливостей розвитку власного духовного «Я» у процесі інтеріоризації набутих від педагога духовних знань); діяльнісно-транслящійному (формування оцінювального ставлення до явищ навколишньої дійсності, реалізація прагнення самостійної духовно-практичної діяльності, екстеріоризація набутого досвіду духовного пізнання). Подібна взаємодія емоційно-когнітивних процесів та ціннісно-смислового поля молодої людини у просторі внутрішнього «Я» дає змогу ефективно вирішувати завдання становлення цілісної духовної особистості. Причому корисними у формуванні духовності курсантів можуть стати як традиційні, так й інноваційні форми аудиторної, позааудиторної та самостійної діяльності студентів (лекції, бесіди, брифінги, дискусії, конференції, участь у розробленні різноманітних культурних проектів або моделюванні заданих ситуацій).

Зауважимо, що серед усіх навчальних дисциплін у вищій школі незалежно від фахового спрямування безперечними лідерами у процесі формування духовності студентської молоді слід визнати культурологічні дисципліни. Адже саме культура фокусує систему ціннісних уяв- 


\section{Koba Oleksandr, Koba Maria}

лень людини, переводячи ії таким чином в якісно інший спосіб буття більш осмислений та впорядкований. У цьому контексті ціннісний зміст культурологічних дисциплін полягає в їх здатності забезпечити курсантів сукупністю знань про смисли і значення культури та уявленнями про ціннісне ставлення до навколишнього світу; збагатити їх культурні потреби та стимулювати до духовно-практичної діяльності.

Крім того, оскільки одним із найефективніших шляхів впливу на внутрішній світ особистості є навколишнє середовище, курсант у стінах закладу вищої освіти крім цілеспрямованого педагогічного впливу педагога повинен «оточувати» світ духовних цінностей, переживання та розуміння яких сприятиме його духовному зростанню. Забезпечити таке «оточення» здатне мистецтво, яке французький філософ М. Дюфренн, розробляючи власну концепцію артизації дійсності, проголошував найвищим типом пізнання, вбачаючи в ньому практично єдиний засіб гальмування деперсоналізації й дегуманізації людини в умовах сучасного суспільства [18, с. 31$]$.

Тож, щоб досягнути мети формування високодуховної особистості, кожен ЗВО нашої держави повинен стати навчально-науковим, культурно-освітнім і виховним центром студентської молоді. Складність полягає в тому, що це має відбуватися в умовах, коли в молодіжному середовищі спостерігається стрімке зростання наркоманії й токсикоманії, захворюваності на СНІД, злочинності; коли розквіт так званої масової культури з властивими їй атрибутами насильства, жорстокості, порнографії, засиллям на телебаченні бойовиків та фільмів жахів досягнув небувалих розмірів; коли щодня посилюється соціально-культурна апатія студентської молоді. Ці негативні процеси відображаються у різноманітних соціологічних дослідженнях, які констатують, що для більшості нинішніх студентів у сфері духовних інтересів головним $€$ телебачення, друге місце посідає «естрадна музика», а такі види мистецтва, як живопис, театр, хореографія, класичні література й музика їм практично незнайомі.

Питання духовного розвитку особистості недаремно набуло сьогодні такої ваги. Його значення завжди зростає в перехідні епохи, що вимагають від людини підвищеної творчої активності, напруження всіх iï духовних сил. Оскільки саме такий час переживає нині наша країна, важливо створити ефективну протидію наміченій тенденції витіснення естетичного середовища на другий план, на периферію усвідомлюваних 


\section{Chapter «Pedagogical sciences»}

завдань. Адже це загрожує небезпечними наслідками - культурним збіднінням життя суспільства й духовним занепадом індивідів, які його утворюють. Недаремно з рівнем духовного розвитку та здатністю особистості сприймати красу й будувати власний світ за ії законами пов'язують найрезультативніші вияви людської творчої енергії, а також загальний прогрес суспільства в усіх галузях життєдіяльності. Оцінюючи сучасні соціокультурні небезпеки, І. Дзюба зазначає, що «втрата багатоманітності природних умов і вражень, радостей і стимулів, монотонність міського побуту і технологізованої праці, стандартизації навчання, інформації, розваг, серійність духовної продукції - все це призводить не тільки до емоційного збіднення життя, а й до зниження моральної чуттєвості, зокрема в пошуках сурогатних і стресових компенсантів утрачених переживань; до послаблення фізичного і психічного здоров'я, до поступового звуження шкали людяності, оскільки розвиток діставатимуть лише ті складники людської вдачі, які «вписуються» в дедалі більшою мірою штучні умови існування» [5, с. 8-9].

Погоджуючись зі справедливістю наведеної думки, вважаємо, що сьогодні процес модернізації вищої освіти має бути головним чином зорієнтований на забезпечення відповідних умов для повноцінного, системного й цілеспрямованого утвердження людського в людині, розвиток тих сил і можливостей, які надають їй можливість будувати власне життя, керуючись загальнолюдськими цінностями.

У такому контексті формування духовності курсантів закладу вищої освіти, їх гармонійний всебічний розвиток неможливі без цілеспрямованого ознайомлення 3 культурними здобутками людства, 3 різними видами мистецтва тощо; без формування у них навички естетичного освоєння навколишньої дійсності. Все це поєднується під загальною назвою - художнє виховання, яке, на нашу думку, в сучасних умовах духовного занепаду українського суспільства повинно посісти у професійній підготовці майбутнього офіцера рівнозначне місце поруч із засвоєнням профільних дисциплін. Саме воно, поєднуючись з аксіологічним впливом усіх навчальних предметів, сприятиме засвоєнню курсантами духовних здобутків нації, адекватній інтерпретації ними мистецьких цінностей і загалом стане дієвим чинником формування духовності молоді, визначаючи ступінь інтелігентності та творчу спрямованість іï прагнень.

Крім того, роль художнього виховання посилюється і з огляду на процеси глобалізації, для яких характерні багатобарвна культурна 


\section{Koba Oleksandr, Koba Maria}

мозаїка, потужний інформаційний потік, суперечливі процеси індивідуалізації і деперсоналізації особистості, що вимагають пошуку нових підходів до виховання людини, здатної виявляти власну унікальність.

Серед негативних наслідків глобалізаційних процесів украй небезпечними $є$ певне «розкультурення» людини, іiі моральна деградація та дегуманізація. У діалозі культур художнє виховання забезпечить узагальнення і поглиблення мистецтвознавчої, культурологічної та естетичної компетенції курсантів, сприятиме формуванню їх гуманістичної спрямованості.

3 огляду на те, що курсантський вік є періодом найінтенсивнішого формування особистості, розвитку професійного мислення й самоствердження, надзвичайної актуальності набуває питання включення художнього виховання в систему навчально-виховної роботи ЗВО. Це вимагає спеціальної педагогічної діяльності, спрямованої на залучення курсантів до скарбниці всесвітньої художньої культури, на духовний розвиток і реалізацію творчого потенціалу особистості, на формування іiї гуманістичної світоглядної позиції. Потрібно усвідомити, що тільки заміна стихійної самоосвіти організованою і контрольованою системою навчальних занять 3 мистецтва здатна підвищити й зробити звичними естетичні потреби. Навчити молоду людину бачити, відчувати й розуміти прекрасне в будь-якому його вияві - основне завдання педагогічного колективу закладу вищої освіти, який прагне сформувати інтелігентну та високодуховну особистість.

Зважаючи на названу мету, художнє виховання у ЗВО повинно спрямовуватись на вирішення низки завдань. По-перше, на забезпечення можливості курсантам продовжувати свою художньо-естетичну освіту, яку вони могли здобути до моменту вступу до закладу вищої освіти. По-друге необхідно створити умови для розвитку здібностей і талантів курсантів, надання допомоги у плануванні та організації дозвілля як у стінах 3ВО, так і за його межами. Це може бути відвідування виставок, музеїв, концертів, театрів, участь у коллективах художньої самодіяльності, різноманітних мистецьких фестивалях. Третє завдання полягає у формуванні в курсантів свідомого прагнення бути активним суб'єктом художнього середовища.

Слід зауважити, що художній розвиток курсантів під час їхнього навчання у ЗВО відбувається не лише під впливом спеціальних виховних заходів. Сюди додається низка демографічних, соціальних, соціаль- 


\section{Chapter «Pedagogical sciences»}

но-психологічних та інших факторів. Серед них: молодіжна і культурна політика держави, соціально-економічний і політичний стан суспільства, профіль ЗВО й його місцезнаходження, індивідуально-психічні особливості молодої людини та наявний рівень і1ї художньої культури.

3 огляду на це досягнення головної мети духовного розвитку курсантів вимагає від професорсько-викладацького складу ЗВО урахування впливу названих чинників у процесі пошуку найефективніших форм і методів роботи, спрямованих на духовне зростання особистості, органічного поєднання навчання, виховання, науково-дослідної та методичної роботи.

У спеціальній літературі, а також на різноманітних конференціях йдеться про необхідність підвищення ролі культури в усіх сферах життєдіяльності людини і суспільства, декларується принцип гуманітаризації освіти, який передбачає посилення ваги гуманітарних знань у системі навчання. Разом $з$ тим доводиться визнати, що нинішні освітні стандарти аж ніяк не спрямовані на посилення ролі культури та мистецтва в навчально-виховному процесі. Нагальним завданням постає виявлення гуманітарного потенціалу кожного елемента навчально-виховної системи ЗВО і посилення культурологічних функцій навчальних дисциплін.

Аналіз сучасного стану забезпечення та організації духовного розвитку курсантів засобами культури та мистецтва дає змогу виокремити низку проблем, основними з яких є такі:

1. У системі художнього виховання ще досить впливовою залишається традиція зосередження педагогічних зусиль не на розвитку власне духовності особистості, а головним чином на висвітленні теоpiї та історії культури та мистецтва. Такий підхід, на нашу думку, є помилковим, оскільки в ньому фактично ігнорується суб'єкт естетичних відносини.

2. У наявній практиці залучення курсантів до світу мистецтва іноді одним видам мистецтва (образотворче, музичне мистецтво, література) віддається перевага, а іншим видам художньої творчості (кіномистецтво, архітектура, театр, ландшафтне мистецтво) належна увага практично не приділяється. Це негативно відбивається на формуванні естетичного досвіду молоді, руйнує цілісність іiї духовного становлення.

3. Занепокоєння викликає й той факт, що культурологічна підготовка майбутніх офіцерів, здатна стати стрижнем духовного виховання студентства, у більшості випадків зводиться лише до лекційних 


\section{Koba Oleksandr, Koba Maria}

занять. При цьому досить рідко та малоефективно використовуються естетико-виховні можливості позааудиторної роботи, діяльності курсантських клубів і молодіжних об'єднань. За таких обставин молодь психологічно налаштовується на формальне сприйняття духовних цінностей людства й не бачить можливостей для реалізації власної активності в галузі духовного самовдосконалення. Зазначені проблемні питання не можуть залишатися поза педагогічною увагою, вимагають осмислення й вирішення за участі фахівців у галузі сучасної психологіï, філософії, педагогіки, культурології і т. ін.

3 метою удосконалення системи духовного розвитку курсантів доцільно використати кілька напрямів роботи. Перший з них передбачає внесення необхідних змін на методологічному рівні, що дасть змогу подолати наявний дещо зневажливий погляд педагогів-предметників на сутність процесу формування духовності курсантів, його місце у структурі професійної підготовки майбутнього офіцера.

Другий напрям удосконалення процесу цілеспрямованого духовного розвитку курсантів скерований на успішне вирішення складного комплексу питань професійно-педагогічного змісту. Вони насамперед пов'язані з діяльністю професорсько-викладацького складу закладу вищої освіти. Адже освіченість викладачів, їх педагогічна майстерність та рівень володіння системою освітніх технологій є одним із головних чинників підвищення ефективності формування духовності курсантів. Сьогодні на зміну вузькопрофільної спеціалізації викладача певної дисципліни повинна прийти висококультурна особистість, педагог з багатим духовним світом.

Зрозуміло, що за наявної соціокультурної кризи для того, щоб «захопити, зацікавити, залучити» курсантів до культурних здобутків людства одного ентузіазму та професіоналізму професорсько-викладацького складу недостатньо. Слабкою ланкою виховного процесу у закладах вищої освіти залишається матеріальне забезпечення. Наявність необхідного навчального обладнання, техніки, пристосованих концертних залів, «курсанських віталень» набагато спрощує процес впливу на духовне становлення курсантів. Ще один негативний момент - стихійний характер духовного розвитку молоді у ЗВО. Відбувається це не лише через недооцінювання його значення, а й, слід бути відвертими, унаслідок небажання певної частини курсантів бути активними співучасниками виховного процесу. 


\section{Chapter «Pedagogical sciences»}

3 огляду на кількість і різноманітність проблем у галузі виховання курсантів, на нашу думку, дієвим чинником підвищення якості та ефективності роботи з художнього виховання у ЗВО України може стати комплексний підхід до їх вирішення. Сутність його грунтується, по-перше, на єдності всіх виховних зусиль і напрямів роботи, націлених на формування духовно багатої та всебічно розвиненої особистості. Під єдністю розуміється насамперед їх взаємопроникнення та використання ними подібних засобів виховного впливу. Головні труднощі, на нашу думку, полягають у нерозробленості сутності, шляхів та засобів окресленого напряму виховання молоді у педагогічній літературі, у прагненні закладів вищої освіти максимально «звузити» простір культурологічних дисциплін задля посилення професійного підготовки. Те, що культурологію включено до навчального плану 3ВО, а світову художню культуру, естетику та мистецтвознавство - у курси за вибором, явно недостатньо. Власне, наявна у закладах вищої освіти система духовно-культурологічного розвитку містить у собі лекційні й практичні заняття зі світової художньої культури, культурології, естетики, роботу молодіжного клубу, клубів за інтересами і т. ін. Вона більш-менш успішно координус роботу бібліотеки, деяких відділень факультетів додаткових та індивідуальних спеціалізацій. Разом з тим спрямовані на формування духовності молоді елементи мають бути також у побуті й навчальній діяльності курсантів, організації праці та відпочинку, оформленні й обладнанні житлових приміщень, зовнішньому вигляді курсанта та їі культурі спілкування.

Комплексний підхід вимагає єдності різних сфер виховання: родини, навчально-виховного закладу, громадських організацій, установ культури й т. ін. Ця єдність включає спільність мети, вимог і зусиль під час вирішення конкретних завдань виховання особистості. Реальний стан речей змушує визнати, що цей напрям використовується у закладах вищої освіти далеко не повністю.

Окремої уваги потребують сер'йозна, кваліфікована пропаганда культурних здобутків людства, ознайомлення з розмаїттям видів і жанрів мистецтва, обгрунтування дієвості тих чи інших ціннісних засад існування людства в сучасних умовах існування цивілізації тощо.

Ці завдання доцільно вирішувати під час проведення різноманітних бесід, дискусій та «круглих столів», публікації проблемних статей у вузівській газеті, виступів на телебаченні тощо. Нарешті, для успіху 


\section{Koba Oleksandr, Koba Maria}

художнього виховання необхідна єдність методів і форм виховання: виховання й самовиховання, виховання й освіти, переконання й примусу, індивідуального підходу й масових форм. Кожне із зазначених протиставлень саме по собі $є$ обов'язковою умовою виховання, а за комплексного підходу вони взаємодіють так, що допомагають у реалізації один одного.

Отже, комплексний підхід - це не підсумовування окремих, різних за змістом процесів. Він $є$ методологічною базою побудови системи виховної роботи, уособлює органічний взаємовплив, взаємопроникнення всіх видів виховання. У системі формування духовності курсантської молоді ефективно співпрацюють такі чинники: художня освіта (курси світової художньої культури, культурології, естетики, спецсемінари з мистецтва й т. ін.), духовно-ціннісний вплив змісту навчального матеріалу фахових дисциплін, позааудиторна робота (клуби, художня творчість, факультети культури, суспільних професій, додаткових спеціалізацій), організація внутрішньовузівського середовища.

Перераховані завдання дають можливість сформулювати низку організаційних принципів, що можуть бути покладені в основу духовного розвитку курсантів. Серед них передусім варто назвати принцип охоплення всього колективу. Особливу увагу слід приділити доцільному сполученню обов'язкових для всіх курсантів форм і видів роботи 3 виховного процесу. Пріоритетним напрямом в організації виховного процесу вищої школи має стати індивідуальний підхід до кожного курсанта, стимулювання його до саморозвитку і духовного пошуку. Саме тому віднесемо до суб'єктів організації виховного процесу Центри культури та організації змістовного дозвілля; клуби за інтересами, бібліотеки, колективи художньої самодіяльності, музеї навчальних закладів, спортивні об'єднання та клуби. Комплексний підхід передбачає максимальне використання всіх їх, що дає можливість, за умови участі курсанта в різних формах роботи, посилити ефективність виховання, і водночас організувати справу до душі, з урахуванням індивідуальних схильностей, здібностей та вмінь молодої людини.

Система духовного виховання курсантів повинна мати відкритий характер. Вона тісно пов'язана не лише з діяльністю внутрішніх структурних підрозділів ЗВО і напрямів навчально-виховного процесу, а й постійно взаємодіє із зовнішнім середовищем, що, у свою чергу, справляє значний вплив на становлення й зміцнення наявної системи 


\section{Chapter «Pedagogical sciences»}

виховної роботи. Організація контактів з навколишнім середовищем завдання дуже важливе й водночас надзвичайно важке, яке можна вирішити за рахунок налагодження співпраці 3 творчими організаціями й установами культури міста, області, країни, різними навчальними закладами міста й т. ін.

Встановлено, що ефективність процесу формування духовності значною мірою залежить від особистісних та професійних якостей викладача, куратора. Саме тому частиною експериментальної роботи було визначено організацію спеціального навчання викладачів. Робота 3 викладачами передбачала вирішення таких завдань: забезпечення усвідомлення педагогами необхідності реалізації суб'єкт-суб'єктної взаємодії в освітньому процесі; розширення кола знань викладачів про сутність духовних цінностей особистості, форми, методи формування та способи діагностики духовності у курсантів, проектування i peaлізація виховної діяльності з урахуванням вікових та індивідуальних особливостей курсантів.

\section{4. Експериментальна перевірка ефективності формування духовності курсантів в навчально-виховному процесі закладу вищої освіти}

Представлено аналіз результатів експерименту в динаміці рівнів сформованості духовності курсантів.

Проведено контрольний експеримент для визначення динаміки рівнів сформованості духовності курсантів у контрольній і експериментальній групах.

Оцінка результатів експериментальної роботи здійснювалася на основі кількісного та якісного аналізу змін у рівнях сформованості духовності курсантів (метод $\lambda$-критерій Колмогорова-Смирнова, $\varphi^{*}$-кутове перетворення Фішера), порівняльного аналізу показників у експериментальних і контрольних групах (метод рангової кореляції Спірмена).

Аналіз результатів дослідження засвідчив факт суттєвого скорочення кількості курсантів з низьким рівнем сформованості когнітивного компоненту духовності в ЕГ (на початку експерименту - 39,2\%, наприкінці - 7,2\%). У КГ динаміка цих процесів виявилась менш помітною, оскільки після завершення експерименту чисельність курсантів 3 низьким рівнем когнітивного компоненту становила $28,4 \%$ 


\section{Koba Oleksandr, Koba Maria}

(до експерименту - 31,2\%). У 21,7\% курсантів ЕГ і 33,3\% КГ констатовано середній рівень сформованості знань про духовність і механізми ії вияву (проти 35,4\% респондентів ЕГ і 33,2\% КГ на початку експерименту).

Отже, в експериментальній групі виявлено більш суттєву динаміку, ніж у контрольній групі.

Рівень сформованості емоційно-ціннісного компоненту духовності курсантів за результатами експерименту, зазнав позитивних змін. Виявлено збільшення кількості респондентів ЕГ, для яких характерна спрямованість на взаємодію, підтримку позитивних взаємин (з 19,2\% до $48,5 \%$ ), у КГ цей показник збільшився лише на $0,8 \%$. Спостерігалася тенденція до збільшення кількості курсантів ЕГ зі спрямованістю на ділову співпрацю (34,6\% - після завершення експерименту, 10,2\% на його початку). Спрямованість на себе діагностували в 16,9\% курсантів ЕГ - після завершення експерименту та 41,2\% - на початку експерименту. Результати контрольного зрізу засвідчили, що в КГ суттєвих змін не відбулось.

На етапі контрольного зрізу проаналізовано рівень сформованості праксичного компоненту духовності курсантів. Результати дослідження засвідчили, що в ЕГ знизилася чисельність респондентів, які виявляють духовність ситуативно (середній рівень сформованості): $40,7 \%$ - на початку експерименту, 16,9\% - після його завершення.

У КГ відбулося зростання лише на 0,8\%. В ЕГ у 34,9\% курсантів встановлено постійний вияв духовності (високий рівень сформованості) - на противагу 8,3\% (на початку експерименту). Водночас зафіксовано зменшення показників низького рівня сформованості праксичного компоненту духовності в ЕГ на 4,9\%, у КГ - тільки на 1,9\%.

Узагальнення показників сформованості духовності учасників ЕГ та КГ після завершення експерименту демонструє позитивну динаміку: високий рівень сформованості духовності властивий $32,8 \%$ респондентів ЕГ та 10,6\% курсантів КГ; достатній рівень зафіксовано у $39,9 \%$ учасників ЕГ та 17,4\% курсантів КГ; середній рівень притаманний 20,1\% курсантам ЕГ та 35,6\% - КГ; низький рівень - 7,2\% респондентів ЕГ та $36,4 \%$ - КГ.

Показники рівнів сформованості духовності курсантів ЕГ на контрольному етапі дослідження значно перевищують показники КГ, що підтверджує ефективність розробленої системи формування духов- 


\section{Chapter «Pedagogical sciences»}

ності курсантів у навчально-виховному процесі закладу вищої освіти та відповідних педагогічних умов.

\section{5. Висновки}

1. Вища школа здатна вирішити надзвичайно складне суспільне завдання щодо формування не лише справжнього професіонала, а й високодуховної особистості.

2. Належна увага до художнього виховання, створення у стінах закладу вищої освіти відповідного культурного середовища, здатного забезпечити передбачуваний виховний вплив.

3. Актуалізація ціннісних домінант вищої професійної освіти, подолання штучної знаннєвої обмеженості фахової підготовки, розкриття аксіологічного потенціалу кожної з навчальних дисциплін та повноцінного використання виховних можливостей предметів культурологічного циклу.

4. Інтеграція внутрішніх та зовнішніх умов розвитку духовності курсантів і концентрація виховних зусиль усього педагогічного колективу цілком спроможні суттєво підвищити ефективність формування цієї інтегративної професійно значущої якості майбутнього офіцера, стимулювати його до свідомої та стійкої орієнтації на духовні цінності в особистісному самовдосконаленні та міжособистісній взаємодії.

Перспективи подальшого дослідження проблеми пов'язані з поглибленим концептуальним аналізом духовності курсантів в сучасних умовах, виявом індивідуальних відмінностей проявів духовності, особливостей їх формування у молоді.

\section{Список літератури:}

1. Андрущенко В. Роздуми про освіт. Статті. Нарисси. Інтерв'ю / В. Андрущенко. - К., 2004. - 738 с.

2. Барвіна Н. О. Художньо-естетична потреба як духовна домінанта сучасної вищої освіти / Н. О. Барвіна // Духовність особистості: методологія, теорія і практика: зб наук. праць / Гол. ред. Г.П. Шевченко. - Вип. 5(74). Сєвєродонецьк: вид-во СНУ ім. Володимира Даля, 2016. - 291 с. - С. 42.

3. Буева Л. П. Человек, культура и образование в кризисном социуме / Л. П. Буева. - М.: Фонд «Новое тысячелетие», 1998. - 168 с.

4. Вернадский В. И. Философские мысли натуралиста / В. И. Вернадский. M., 1988.

5. Духовно-культурні цінності виховання людини: монографія / Шевченко Г. П., Антоненко Т. Л., Бєлих О. С., Зеленов С. А., Карпенко І. М., 


\section{Koba Oleksandr, Koba Maria}

Крсек О. С., Рашидова С. С., Рашидов С. Ф., Фунтікова Н. В., Шайкіна О. О. Луганськ: Ноулідж, 2013. - 332 с.

6. Зинченко В. П. Размышления о душе и ее воспитании (час души) /

В. П. Зинченко // Вопр. философии. - 2002. - № 2. - С. 119-136.

7. Коханович Л. И. Гуманитарная среда вуза и гуманитарное образование / Л. И. Коханович. - М.: НИИВО, 1995. - 144 с.

8. Крымский С. Б. Контуры духовности: новые контексты идентификации / С. Б. Крымский // Вопр. философии. - 1992. - № 2. - С. 15-23.

9. Кулюткин Ю. Н. Технократия и гуманизм / Ю. Н. Кулюткин // Информационный бюллетень: Проблемы непрерывного образования: педагогические кадры. - СПб. ; Новгород ; Псков, 1995. - С. 8-11.

10. Семиченко В. А. Психология эмоций / В. А. Семиченко. - Луганск: НПФ «Осирис», 1996. - 164 с.

11. Сипченко В. І. Гуманістична спрямованість навчально-виховного процесу у вищій школі / В.І.Сипченко // Теоретичні питання освіти та виховання: зб. наук. пр. / за заг. ред. М. Б. Свтуха. - К.: Видав. центр КДЛУ, 2000. Вип. 8. - С. 73-74.

12. Сухомлинський В. О. «Виховання почуттів» / В. О. Сухомлинський // Вибрані твори: в 5 т. - К.: Рад. шк., 1977. - Т. 5. - 639 с.

13. Ушинський К.Д. Вибр. пед. тв. Т. І. - К., 1983. - 352 с.

14. Человек в мире художественной культуры. Приобщение к искусству: процесс и управление. - М., 1982. - 186 с.

15. Шевченко Г. П. Проблеми духовності людини XXI століття / Г. П. Шевченко // Духовність особистості: методологія, теорія і практика: зб. наук. пр.; гол. редактор Г. П. Шевченко. - Вип. 5. - Луганськ: вид-во СНУ ім. В. Даля, 2012. - С. 241-250.

16. Энциклопедический словарь по культурологии / под ред. проф. А. А. Радугина. - М.: Центр, 1997. - 264 с.

17. Шевченко Г. П. Виховання - процес людинотворчості, культуротворчості, духотворчості // Духовність особистості: методологія, теорія і практика: збірник наукових праць / Гол. ред. Г. П. Шевченко. - Вип. 3(66). Сєвєродонецьк: вид-во СНУ ім. В. Даля, 2015. - С. 288-298.

18. Hofstede G. Culture's Consequences, Comparing Values, Behaviors, Institutions, and Organizations Across Nations. Thousand Oaks CA: Sage Publications, 2001.

\section{References:}

1. Andrushchenko V. (2004). Reflections on education. Articles. Sketchbook Interview. K.: 556-559.

2. Barvina N. (2016). Art-aesthetic need as the spiritual dominant of modern higher education. Spirituality of personality: methodology, theory and practice: sy sci. Works. Severodonetsk: View of the SNU them. Volodymyr Dahl, 5(74): 42-43.

3. Bueva L. (2014). Man, Culture and Education in a Crisis Stuff. M.: The New Millennium Foundation: 72-77.

4. Vernadsky V. (2016). Philosophical Thoughts of the Naturalist. M.: 12-16. 
5. Shevchenko, G., Antonenko, T. \& Belich, O. (2002). Spiritual and cultural values of education of a person: a monograph. Lugansk: 42-46.

6. Zinchenko V. (2012). Reflections on the soul and its upbringing (hour of soul). Vopr. philosophy, 2: 119-136.

7. Kokanovich L. (2015). Humanitarian environment of high school and humanitarian education. M.: NIIVO: 121-125.

8. Krymsky S. (2012). Contours of Spirituality: New Contexts of Identity. Vopr. philosophy, 2: 15-23.

9. Kulyutkin Y. (2005). Technocracy and Humanism. Informational Bulletin: Problems of Continuing Education: Pedagogical Personnel. Petersburg, Novgorod, Pskov: 8-11.

10. Semichenko V. (2016). Psychology of emotions. Lugansk: NPF Osiris: 69-73.

11. Sipchenko V. (2009). Humanistic orientation of the educational process in high school. Theoretical issues of education and education: Sb. sciences etc. K.: Issued. Center KDLU. 8: 73-74.

12. Sukhomlinsky V. (2017). Education of the senses. Selected works. K., 5: 224-228.

13. Ushinsky K. (1983). Vibrate ped. tvoru. K., I: 352.

14. Man in the world of artistic culture. Applying to art: process and management. (2002). Moscow: 186.

15. Shevchenko G. (2012). Problems of Human Spirituality of the XXI Century. Personality: Methodology, Theory and Practice. Lugansk: View of the SNU them. V. Dal, 5: 241-250.

16. Radugin A. (1997). Encyclopedic Dictionary on Culturology. M.: Center: 264.

17. Shevchenko G. (2015). Education - the process of human creativity, cultural cultivating, spirit-creativity. Spirituality of personality: methodology, theory and practice: a collection of scientific works. Severodonetsk: View of the SNU them. V. Dahl, 3(66): 288-298.

18. Hofstede G. (2011). Culture's Consequences, Comparing Values, Behaviors, Institutions, and Across Nations. Thousand Oaks CA: Sage Publications: 57-62. 